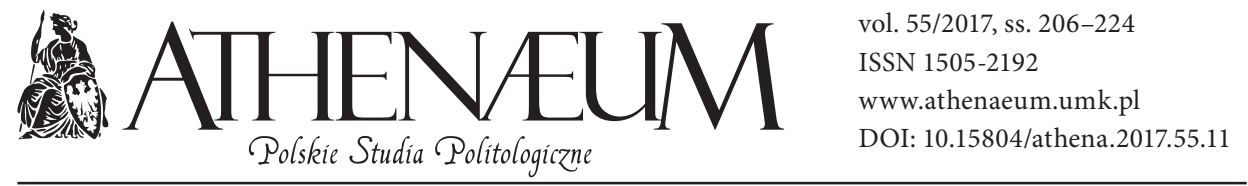

\title{
HYDROPOLITYKA W REGIONIE DOLNEGO BIEGU RZEKI MEKONG. OWOCNA WSPÓŁPRACA CZY KRUCHY SOJUSZ PAŃSTW INDOCHIŃSKICH?
}

\author{
HYDROPOLITICS OF THE LOWER MEKONG BASIN: \\ FRUITFUL COOPERATION OR FRAGILE ALLIANCE \\ OF THE INDOCHINESE STATES?
}

\author{
Michał Zaręba*
}

\begin{abstract}
ABSTRAKT
Rzeka Mekong, przepływająca przez Chiny, Birmę/Mjanmę, Laos, Tajlandię, Kambodżę oraz Wietnam, tworzy dorzecze, od którego zależy byt ponad $70 \mathrm{mln}$ ludzi. Sytuacja w regionie ma szczególne znaczenie dla rybołówstwa i rolnictwa w ostatnich czterech z grupy wymienionych powyżej państw. $Z$ tego też względu już od lat 50. XX wieku wspomniane kraje indochińskie współpracują wokół zasobów Mekongu, tworząc regionalne organizacje integracyjne. $\mathrm{W}$ ostatnich latach największą uwagę $\mathrm{w}$ dorzeczu przykuwa hydroenergetyka. Mimo zagrożeń, jakie niesie za sobą budowa dużych i licznych elektrowni wodnych, państwa Półwyspu Indochińskiego, w szczególności Laos i Kambodża, planują rozwój swojego potencjału. Celem artykułu jest analiza relacji hydropolitycznych $\mathrm{w}$ dolnym biegu rzeki Mekong, zwłaszcza w perspektywie nowych
\end{abstract}

\begin{abstract}
The Mekong River which runs through China, Myanmar, Laos, Thailand, Cambodia, and Vietnam creates basin where more than 70 million people live. Situation in this region has great influence on agriculture and fishery, particularly in the last four aforementioned countries. Therefore those states has been cooperating with each other over the water resources since the 1950s. Nowadays, attention is focused on hydroenergy. Despite the fact that growing number of hydropower plants poses a threat for the environment, the Lower Mekong Basin countries, like Laos and Cambodia, are planning to exploit their hydropower potential. The main purpose of this article is to analyze hydropolitical relations between the LMB states, especially in the face of new challenges like functioning of hydroelectric power stations in China and development of water
\end{abstract}

\footnotetext{
* Uniwersytet Łódzki, Wydział Studiów Międzynarodowych i Politologicznych.
} 
wyzwań takich jak budowa potężnych obiektów w chińskiej części dorzecza i plany hydroenergetycznej ekspansji w Indochinach. Praca daje odpowiedź na pytanie, czy wskazane powyżej czynniki sprzyjają współpracy, czy też generują coraz więcej konfliktów pomiędzy Laosem, Tajlandią, Wietnamem i Kambodżą.

Słowa klucze: hydropolityka, dorzecze Mekongu, kraje dolnego biegu rzeki Mekong energy potential of the Indochinese Peninsula. Paper gives an answer whether factors listed above foster cooperation among the LMB states or create potential sources of conflicts between those countries.

Keywords: hydropolitics, Mekong River Basin, Lower Mekong Basin countries

\section{WSTĘP}

Po zakończeniu II wojny światowej Organizacja Narodów Zjednoczonych zdecydowała się udzielić większego wsparcia państwom azjatyckim. Ta decyzja zaowocowała powołaniem w 1947 roku Komisji Gospodarczej Narodów Zjednoczonych ds. Azji i Dalekiego Wschodu (ECAFE - Economic Commission for Asia and the Far East). Automatycznie w skład ECAFE weszły Chiny i Tajlandia (ówczesny Syjam), jednak problem dla funkcjonowania komisji stanowił konflikt w Wietnamie i francuskie zwierzchnictwo nad koloniami w Indochinach. Sytuację skomplikowała również proklamacja Chińskiej Republiki Ludowej w 1949 roku, której nie uznały Narody Zjednoczone. Po zakończeniu I wojny indochińskiej w 1954 roku i wejściu w życie porozumień genewskich kończących konflikt do ECAFE przystąpiła Kambodża, Wietnam Południowy, a rok później Laos. Odrzucono natomiast kandydaturę Wietnamczyków z północy. W marcu 1957 roku NZ zaprezentowały raport „Rozwój zasobów wody w dolnym biegu Mekongu” („Development of Water Resources in the Lower Mekong”), który potwierdził potencjał hydroenergetyczny regionu i wskazał na korzyści rozbudowy systemów irygacyjnych w dorzeczu (F. Molle, T. Foran, P. Floch, 2009). Krajom dolnego biegu rzeki zaproponowano stworzenie organizacji regionalnej, która miałaby czuwać nad zrównoważonym zarządzaniem wodami dorzecza i zacieśnić współpracę państw indochińskich wokół zasobów Mekongu. Pomysł zyskał aprobatę zainteresowanych stron, co dało początek instytucjonalnej współpracy w dolnym biegu rzeki. 


\section{DORZECZE MEKONGU ORAZ ZNACZENIE ZASOBÓW RZEKI DLA PAŃSTW DOLNEGO BIEGU}

Mekong to jedna z największych rzek Azji, przekraczająca 4900 km długości. Swój początek bierze w Chinach, a dokładniej w prefekturze Yushu w prowincji Qinghai, gdzie topniejące śniegi góry Guosongmucha tworzą jego źródła. Zwany przez miejscowych Niespokojną Rzeką (Lancang Jiang), przepływa kolejno przez Tybetański Region Autonomiczny oraz prowincję Yunnan, dzieląc częściowo terytoria Chin i Birmy. Mekong tworzy blisko stukilometrowe pogranicze birmańsko-laotańskie, a następnie przepływa przez północny Laos, gdzie zasilany jest przez system rzeczny Nam Ou. Kolejno wyznacza 850-kilometrową linię graniczną między Laosem a Tajlandią. Na tym odcinku jego sytuacja hydrologiczna uzależniona jest od rzek Nam Ngum i Nam Theun, a także od tajskich dorzeczy Mun oraz Chi. Wzburzony Mekong wpływa do Kambodży, okalając liczne wysepki oraz tworząc najszersze na świecie wodospady Khone Phapheng. Następnie powiązany jest z systemem rzek Se Kong, Se San oraz Sre Pok - jednym z największych zlewisk regionu. W okolicach Phnom Penh Mekong zasila rzekę i jezioro Tonle Sap, które w porze deszczowej kilkakrotnie zwiększa swoją powierzchnię. Przepływając przez terytorium Wietnamu, uchodzi do Morza Południowochińskiego, tworząc rozległą deltę o dziewięciu odnóżach, stąd też nazywany jest przez miejscowych Rzeką Dziewięciu Smoków (mapa 1).

Dorzecze Mekongu zajmuje powierzchnię $795000 \mathrm{~km}^{2}$, z czego aż $3 / 4$ przypada na tereny dolnego biegu rzeki, czyli Laosu (25\%), Tajlandii (23\%), Kambodży (20\%) oraz Wietnamu (8\%). Region ten zasiedla około 70 mln ludzi i w znacznej mierze są to obywatele wymienionych powyżej państw indochińskich. Największą grupę, bo ok. $23 \mathrm{mln}$, stanowią Tajowie, zamieszkujący głównie tereny Isanu, oraz Wietnamczycy. Zdecydowana większość z 19 mln populacji wietnamskiej części dorzecza zasiedla tereny delty, której gęstość zaludnienia jest największa w całym regionie. Mimo że Kambodżanie i Laotańczycy stanowią łącznie mniejszą grupę niż Tajowie czy Wietnamczycy, to należy zaznaczyć, że liczba ludności zamieszkującej dorzecze Mekongu stanowi między 80 a 90\% populacji tych dwóch państw (tabela 1).

Dla 60 mln mieszkańców dolnego biegu rzeka to głównie źródło wody pitnej oraz istotny szlak komunikacyjny. Jednak przede wszystkich dorzecze stwarza idealne warunki dla rolnictwa, a bogactwo flory i fauny czyni ten region największym łowiskiem śródlądowym na świecie. Badania wskazują, że aż 68\% osób mieszkających w dolnym biegu Mekongu trudni się rybołówstwem, rolnictwem 


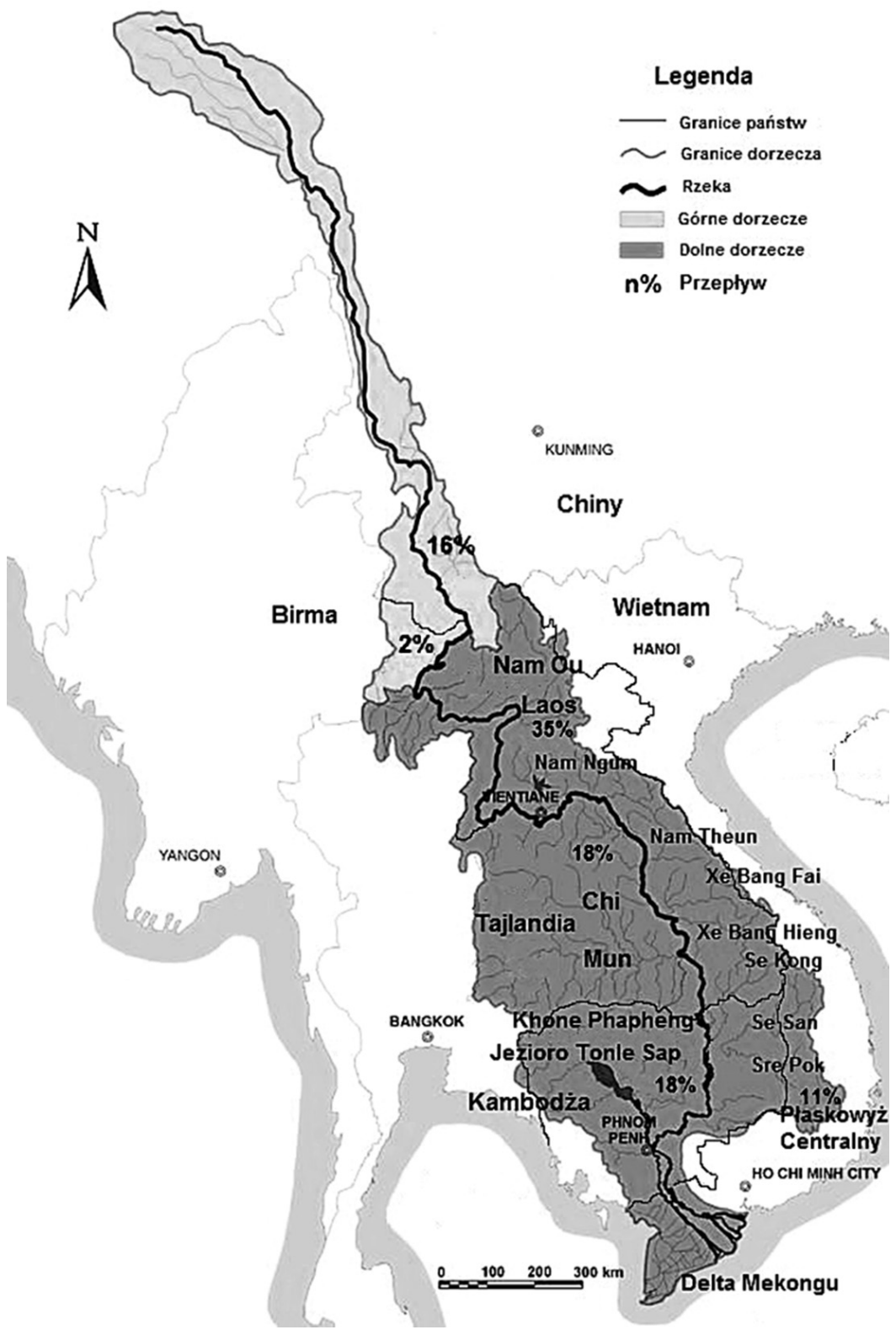

Mapa 1. Dorzecze Mekongu

Źródło: Tilt (2014). 
Tabela 1. Populacja regionu i geograficzna kontrola nad dorzeczem Mekongu

\begin{tabular}{|l|l|c|c|c|c|}
\hline \multicolumn{2}{|c|}{} & $\begin{array}{c}\text { Powierzchnia } \\
\text { dorzecza } \\
\left(\mathbf{k m}^{2}\right)\end{array}$ & $\begin{array}{c}\text { Powierzchnia } \\
\text { dorzecza (\%) }\end{array}$ & $\begin{array}{c}\text { Populacja } \\
\text { dorzecza } \\
(\mathbf{m l n})\end{array}$ & $\begin{array}{c}\text { Populacja } \\
\text { dorzecza (\%) }\end{array}$ \\
\hline \multirow{4}{*}{$\begin{array}{l}\text { Kraje dolnego } \\
\text { biegu }\end{array}$} & Laos & 202000 & 25 & 5 & 8 \\
\cline { 2 - 6 } & Wietnam & 65000 & 8 & 19 & 27 \\
\cline { 2 - 6 } & Tajlandia & 184000 & 23 & 23 & 33 \\
\cline { 2 - 6 } & Kambodża & 155000 & 20 & 13 & 18 \\
\cline { 2 - 6 } & Razem & $\mathbf{6 0 6 0 0 0}$ & $\mathbf{7 6}$ & $\mathbf{6 0}$ & $\mathbf{8 6}$ \\
\hline \multirow{2}{*}{$\begin{array}{l}\text { Kraje górnego } \\
\text { biegu }\end{array}$} & Chiny & 165000 & 21 & 10 & 14 \\
\cline { 2 - 6 } & Birma & 24000 & 3 & - a & - a \\
\hline \multicolumn{2}{|c|}{ Razem } & $\mathbf{7 9 5 0 0 0}$ & $\mathbf{1 0 0}$ & $\mathbf{7 0}$ & $\mathbf{1 0 0}$ \\
\hline
\end{tabular}

Źródło: Goh (2007), MRC (2011).

a birmańska część dorzecza Mekongu jest zamieszkana przez około 23 tys. osób.

czy też zbieractwem, a dla 38\% osadników korzystanie z dobrodziejstw rzeki generuje dodatkowe źródło dochodu (MRC - Mekong River Commission, 2011).

Ok. 22\% światowych śródlądowych połowów ryb i innych zwierząt wodnych odbywa się w dorzeczu Mekongu. Z ponad 2,7 mln ton złowionych w regionie ryb ok. $34 \%$ pochodzi z tajskiej części dorzecza (tabela 2). Tam połowy sięgają rzędu 936 tys. ton, co stanowi 85\% śródlądowego rybołówstwa Tajlandii (Bartley, Jorgensen, 2010).

Zasobny w ryby jest również wietnamski region Płaskowyżu Centralnego oraz delta Mekongu, w której łapie sie łącznie ok. 920 tys. ton ryb - ok. 40\% połowów w rzekach kraju (GSOV - General Statistic Office of Vietnam, 2011). Co więcej, w porze suchej, kiedy poziom Mekongu i jego dopływów jest niski, a na tereny delty dostaje się słona woda z Morza Południowochińskiego, miejscowi rybacy mają również okazję łowić krewetki. Kambodżańskie rybołówstwo z kolei w dużej mierze opiera się na połowach w dorzeczu Mekongu. Stąd pochodzi ponad 670 tys. ton ryb - 80\% połowów całego kraju, mimo że nadal na szeroką skalę stosowane są tradycyjne metody pozyskiwania ryb (Gillett, 2004). Największe znaczenie dla rybołówstwa Kambodży ma jezioro Tonle Sap, które w porze deszczowej nawet sześciokrotnie zwiększa swoją powierzchnię. Na Laos przypada zaledwie 8\% połowów w dorzeczu Mekongu, co jednak przekłada się na 230 tys. ton złowionych ryb, czyli 78\% rybołówstwa kraju (Baran, Jantunen, Chong, 2007). 
Tabela 2. Rybołówstwo i rolnictwo w krajach dolnego biegu rzeki Mekong

\begin{tabular}{|l|c|c|c|c|c|c|}
\hline \multirow{2}{*}{ Kraj } & \multicolumn{3}{|c|}{ Rybołówstwo 2008 (tys. ton rocznie) } & \multicolumn{2}{c|}{ Zbiory ryżu 2005 } \\
\cline { 2 - 7 } & Ryby & $\begin{array}{c}\text { Inne } \\
\text { zwierzęta }\end{array}$ & Suma & $\%$ & $\begin{array}{c}\text { (tys. ton } \\
\text { rocznie) }\end{array}$ & $\%$ \\
\hline Kambodża & 555 & 121 & 676 & 25 & 5986 & 16 \\
\hline Laos & 185 & 45 & 230 & 8 & 2568 & 7 \\
\hline Tajlandia & 740 & 196 & 936 & 34 & 8272 & 23 \\
\hline Wietnam & 746 & 173 & 919 & 33 & 20015 & 54 \\
\hline Delta Mekongu & & & & & 19298 & 52 \\
\hline Płaskowyż Centralny & & & & & 717 & 2 \\
\hline Suma & 2226 & 535 & 2761 & 100 & 36841 & 100 \\
\hline
\end{tabular}

Źródło: MRC (2010), GSOV (2011)

Szacuje się, że pola uprawne w dorzeczu Mekongu zajmują obszar $323656 \mathrm{~km}^{2}$, co stanowi ponad $40 \%$ powierzchni całego regionu. Największe połacie ze wspomnianej liczby stanowią tereny uprawne w Wietnamie (42\%) oraz w Tajlandii (32\%), a zaledwie 8 i 7\% powierzchni zajmują pola Kambodży i Laosu (Snidvongs, Teng, 2006). Obliczenia wskazują, że ok. 80\% upraw w dorzeczu Mekongu stanowi ryż. Ponad 50\% zbiorów tego zboża, czyli ok. $20 \mathrm{mln}$ ton, pozyskuje się w Wietnamie, z czego zdecydowaną większość w samej delcie (tabela 2). Region zwany jest „miską ryżu” lub „spichlerzem”, ponieważ zbiory w tej części Wietnamu sięgają ok. 56\% krajowych zbiorów, a sektor rolnictwa zatrudnia blisko 80\% mieszkańców delty (GSOV, 2011). Mimo dużego areału pól uprawnych w tajskiej części regionu zbiory ryżu przekraczające $8 \mathrm{mln}$ ton (23\% plonów dorzecza Mekongu) odpowiadają zaledwie za 1/4 krajowej produkcji. Rolą trudni się aż 70\% ludności północno-wschodniej części Tajlandii, pomimo nieprzychylnych warunków. Piaszczyste i zasolone gleby utrudniają uprawę mokrego ryżu, dlatego też Mekong i jego dopływy stanowią istotne źródło wody używanej do celów irygacyjnych. W Kambodży rolnictwo zatrudnia blisko $80 \%$ ludności. W regionie Mekongu pozyskuje się niecałe $6 \mathrm{mln}$ ton ryżu, czyli ok. 16\% zbiorów dorzecza i 65\% produkcji krajowej. Górzyste ukształtowanie powierzchni Laosu sprawia, że zaledwie 16\% terenów w tym państwie nadaje się pod uprawę. Co więcej, nadal powszechnie stosowany jest przestarzały system żarowy, co powoduje wyjałowienie gleby. Te czynniki sprawiają, że w laotańskiej 
części dorzecza Mekongu zbiera się tylko 2,5 mln ton ryżu - 7\% plonów regionu Mekongu, co stanowi jednak aż 3/4 zbiorów kraju (MRC, 2010).

Największa uwaga skupiona jest jednak na potencjalne hydroenergetycznym dorzecza Mekongu. Jest on szacowany na blisko $70000 \mathrm{MW}$, a ponad połowa możliwości w energetyce wodnej przypada na Chiny (tabela 3). Spośród państw dolnego biegu największym potencjałem hydroenergetycznym szczyci się Laos - ok. 35\% możliwości całego regionu i ponad 70\% dolnej części dorzecza. $\mathrm{Na}$ drugim miejscu plasuje się Kambodża, na którą przypada 8,6\% potencjału regionu i 18\% możliwości dolnego biegu Mekongu.

Tabela 3. Potencjał hydroenergetyczny dorzecza Mekongu

\begin{tabular}{|c|c|c|c|}
\hline & & $\begin{array}{c}\text { Potencjał hydroenergetyczny } \\
\text { (MW) }\end{array}$ & $\begin{array}{c}\text { Potencjał hydroenergetyczny } \\
(\%)\end{array}$ \\
\hline & Laos & 24160 & 35 \\
\hline & Tajlandia & 796,5 & 1,1 \\
\hline $\begin{array}{l}\text { Dolny bieg } \\
\text { rzeki }\end{array}$ & Kambodża & 5978,5 & 8,6 \\
\hline & Wietnam & 2842 & 4,1 \\
\hline & Razem & 33777 & 48,8 \\
\hline Górny bieg & Chiny & 35611 & 51 \\
\hline rzeki & Birma & 156 & 0,2 \\
\hline & azem & 69544 & 100 \\
\hline
\end{tabular}

Źródło: Zaręba (2015).

Jak dotąd największe obawy ekspertów budził rozwój hydroenergetyki w Państwie Środka, które rozwinęło ponad 50\% swojego potencjału. W chińskiej części dorzecza zrealizowano bowiem już sześć dużych inwestycji. Powstały obiekty Manwan (1650 MW), Dachoashan (1350 MW), Xiaowan (4200 MW), Jinghong (1750 MW), Nuozhadu (5850 MW) oraz Gongguoqiao (900 MW), a kolejne trzy - Miaowei (1400 MW), Huangdeng (1900 MW), Wunonglong (900 MW) są na ukończeniu (Zaręba, 2015). Ekspansja hydroenergetyczna w Chinach zachęciła państwa indochińskie, zwłaszcza Laos i Kambodżę, do inwestycji w tym sektorze. Liczą one, że rozwój energetyki wodnej przyniesienie duże wpływy do ich budżetów. Mimo wielu ostrzeżeń i problemów, przed którymi stanęły kraje dolnego biegu na skutek funkcjonowania tam w ChRL, nic nie zapowiada, aby plany budowy elektrowni wodnych w Indochinach zostały wstrzymane. 


\section{HYDROPOLITYCZNA CHARAKTERYSTYKA DORZECZA DOLNEGO MEKONGU}

W latach 60. i 70. hydroelektrownie w regionie dolnego biegu rzeki powstawały głównie w Tajlandii. Dopiero po ustabilizowaniu się sytuacji na Półwyspie Indochińskim zrealizowano pierwszą poważną inwestycję w Laosie, kiedy to w 1984 roku oddano do użytku hydroelektrownię Nam Ngum 1 o mocy 155 MW. Wzrost zainteresowania energetyką wodną w Indochinach i początek hydroenergetycznego podboju dorzecza przypada jednak dopiero na lata 90. W 1994 roku w Tajlandii ukończono bowiem budowę obiektu Pak Mun (136 MW), a w Laosie odpowiednio cztery i pięć lat później uruchomiono dwie duże elektrownie wodne - Theun Hinboun (220 MW) oraz Houay Ho (150 MW). Tajlandia, zachęcona udanymi inwestycjami w regionie Menamu (Chao Phraya), takimi jak Bhumibol (749 MW), Sirikit (500 MW) czy Srinagarind (720 MW), chciała zwiększyć ich liczbę również w dorzeczu Mekongu. Rząd spotkał się jednak z niespodziewanym oporem społeczności lokalnej już trakcie przygotowań terenów pod budowę elektrowni Pak Mun, a protesty mieszkańców przybrały na sile na przełomie lat 90. i 2000. (Foran, Manorom, 2009). Na skutek niezadowolenia ludności dorzecza Mekongu, obawiającej się strat w rybołówstwie czy rolnictwie, Tajlandia zdecydowała się zarzucić plany hydroenergetycznej ekspansji wraz z wybudowaniem w 2001 roku elektrowni o mocy $500 \mathrm{MW}$ na istniejącym już jazie Lam Ta Khong. Z uwagi na liczne demonstracje rząd wstrzymał również budowę kilku tam i systemów przerzutu wody w tajskim dorzeczu Mekongu. Postawiono na eksport $\mathrm{z}$ innych krajów regionu, co wydawało się dobrym wyborem, zwłaszcza że sąsiedni Laos wkraczał właśnie na ścieżkę hydroenergetycznego boomu.

Należy jednak pamiętać, że początek nowego stulecia pod względem rozwoju energetyki wodnej należał do Wietnamu. W 2001 roku oddano bowiem do użytku hydroelektrownię Yali Falls o mocy 720 MW, choć już w latach 90. na Rzece Czarnej na północy kraju powstał bardziej imponujący obiekt - Hoa Binh (1920 MW). Udana inwestycja w postaci YF była tylko dowodem na słuszność działań w regionie Płaskowyżu Centralnego. W konsekwencji powstało tam kolejnych 11 obiektów na czele z wybudowaną w 2006 roku elektrownią Se San 3 o mocy 260 MW, Se San 4 (360 MW), oddaną rok później, czy obiektami Buon Kuop (280 MW) i Sre Pok 3 (220 MW), ukończonymi w 2009 roku. Ostatnią inwestycją była hydroelektrownia Upper Kontum (220 MW), oddana do użytku dwa lata później, czyli w tym samym roku co największa elektrownia wodna Wietnamu Son La (2400 MW) położona na północy kraju. 


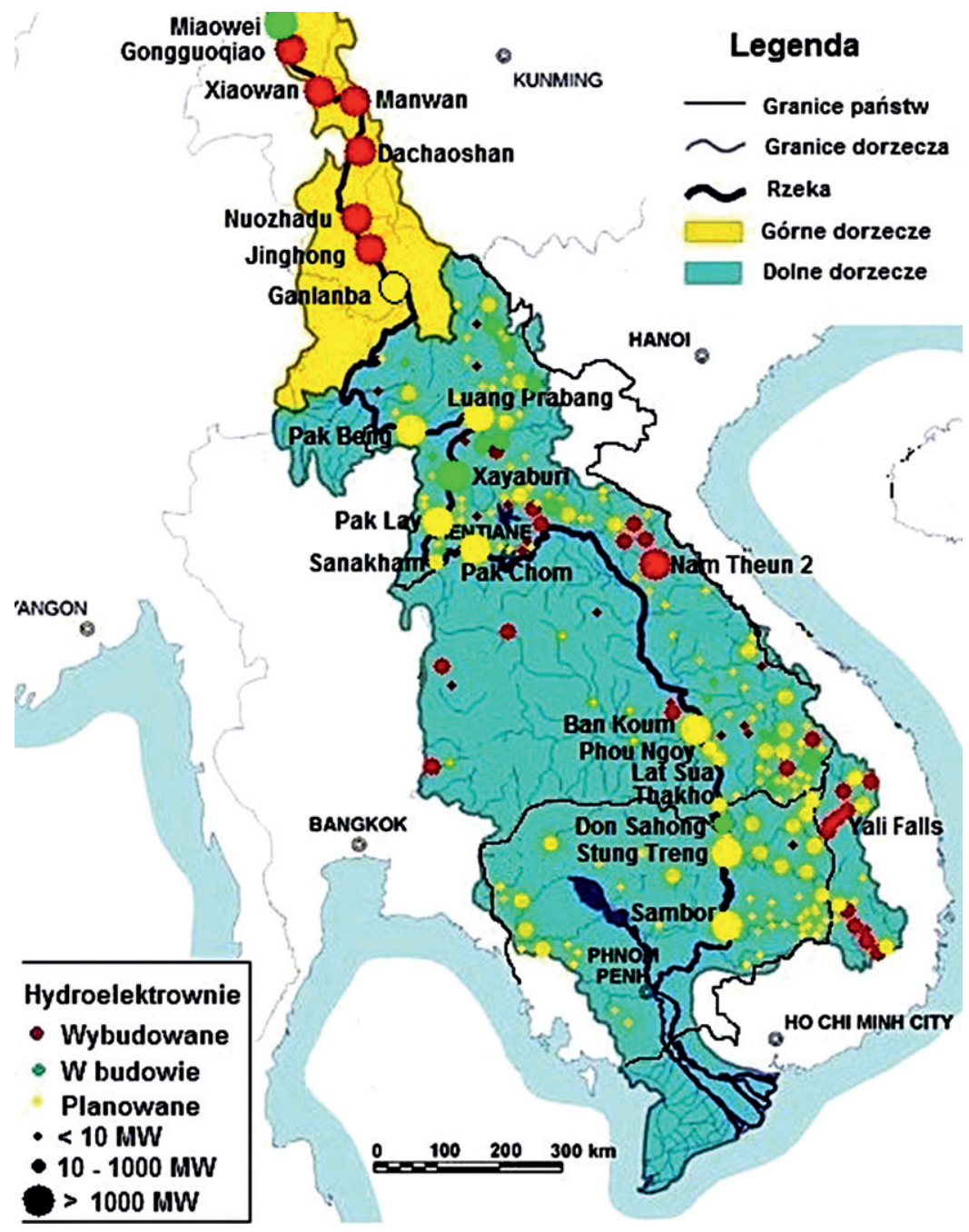

Mapa 2. Elektrownie wodne w dorzeczu dolnego Mekongu

Źródło: opracowanie własne.

Tymczasem w Laosie jeszcze w 2010 roku doszło do finalizacji dwóch dużych inwestycji. Ukończono budowę obiektu Nam Lik 2 (100 MW), ale przede wszystkim powstała najpotężniejsza w tym kraju hydroelektrownia Nam Theun 2 o mocy 1070 MW. Koszt realizacji przedsięwzięcia wyniósł blisko 
1,5 mld dolarów, co czyni inwestycję największą w Laosie (Lawrence, 2009). Rok później powstał obiekt Nam Ngum 2 (615 MW), w 2012 roku hydroelektrownia Nam Ngum 5 (120 MW), a w 2013 roku Xekaman 3 (250 MW). W tym czasie dobudowano również drugi przełom elektrowni Theun Hinboun, zwiększając jej moc o $230 \mathrm{MW}$.

Tabela 4. Elektrownie w dorzeczu dolnego Mekongu

\begin{tabular}{|l|c|c|c|c|c|}
\hline & Laos & Tajlandia & Kambodża & Wietnam & Razem \\
\hline Wybudowane & 21 & 9 & 1 & 13 & 44 \\
\hline W budowie & 17 & 0 & 0 & 0 & 17 \\
\hline Planowane & 94 & 6 & 49 & 9 & 158 \\
\hline Razem & 132 & 15 & 50 & 22 & 219 \\
\hline
\end{tabular}

Źródło: Zaręba (2015).

Obecnie w dolnej części dorzecza Mekongu istnieją 44 hydroelektrownie, z których największą mocą instalacyjną dysponuje wietnamska Yali Falls i laotańska NT2. Na uwagę jednak zasługują przede wszystkim plany, jakie snują kraje indochińskie. O ile Tajlandia i Wietnam mają zamiar wybudować kilka mniejszych obiektów, o tyle wizja laotańska i kambodżańska może wprawiać w osłupienie (tabela 4). W głównym nurcie Mekongu ma funkcjonować 14 elektrowni wodnych, z czego aż 12 w Laosie. Obecnie trwa już budowa tamy Don Sahong (360 MW) oraz obiektu Xayaburi, który będzie miał zainstalowane turbiny o mocy 1260 MW. Planuje się jednak konstrukcję jeszcze potężniejszych elektrowni wodnych. Na północy w niedalekiej przyszłości mają powstać obiekty Pak Beng (1300 MW), Luang Prabang (1400 MW), Pak Lay (1320 MW), Pak Chom (1079 MW) czy nieco mniej znacząca tama Sanakham (500 MW). Z kolei w południowej części kraju będą działać równie imponujące hydroelektrownie takie jak Ban Koum (2330 MW), Phou Ngoy (651 MW), Lat Sua (800 MW), czy obiekty o mniejszej mocy instalacyjnej - Thakho (172 MW) i Tad Samphamit (56 MW). Stawkę mają uzupełnić dwie hydroelektrownie położone na terenach Kambodży, czyli Sambor (2600 MW) oraz Stung Treng (980 MW). Co więcej, Laos pracuje już m. in. nad stworzeniem kaskady ośmiu obiektów na rzece Nam Ou (o łącznej mocy 2000 MW), a Kambodża chce zbudować hydroelektrownie w dolnym odcinku Se San (3 obiekty o łącznej mocy 375 MW) i Sre Pok (trzy elektrownie - $790 \mathrm{MW}$ ). 
Na uwagę zasługuje również zainteresowanie innych krajów regionu sektorem energetyki wodnej w Laosie i Kambodży (tabela 5). Przedsiębiorstwa z Chin zaangażowane są m.in. w projekty Sambor, Pak Beng, Pak Lay, Sanakham, czy kaskadę na rzece Nam Ou. Wietnamczycy mają brać udział w realizacji przedsięwzięcia Stung Treng oraz Luang Prabang, a Tajowie skierowali wzrok w stronę Xayaburi, Lat Sua, Phou Ngoy i Ban Koum.

Tabela 5. Firmy z państw zaangażowanych w budowę elektrowni wodnych w Laosie i Kambodży

\begin{tabular}{|c|c|c|c|c|}
\hline & \multicolumn{4}{|c|}{ Inwestorzy } \\
\hline Kraj & Chiny & Wietnam & Tajlandia & Inne \\
\hline Laos & 24 & 17 & 21 & 26 \\
\hline Kambodża & 3 & 4 & 0 & 4 \\
\hline
\end{tabular}

Źródło: Zaręba (2015).

Rzeka Mekong posiada niezwykły potencjał hydroenergetyczny. Korzyści z rozwoju energetyki wodnej mogą odnieść zarówno kraje, w których powstaną elektrownie, jak i inwestujące przedsiębiorstwa $\mathrm{z}$ innych państw regionu czy świata. Skomplikowana sieć powiązań może zacieśnić współpracę między stronami zainteresowanymi sytuacją w dorzeczu. Hydroenergetyczny boom stwarza jednak także ryzyko pojawienia się nieporozumień i może doprowadzić do konfliktów między państwami dolnego biegu rzeki.

\section{HYDROPOLITYKA W RELACJACH PAŃSTW DOLNEGO MEKONGU}

Dostrzeżony potencjał hydroenergetyczny dorzecza oraz konieczność stworzenia mechanizmów rozsądnego i sprawiedliwego zarządzania wodami regionu były głównym powodem powołania 17 września 1957 roku Komitetu ds. Koordynacji i Badań Dolnego Mekongu (Committee for Coordination of Investigations of the Lower Mekong), zwanego potocznie Komitetem Mekongu (Mekong Committee) (Delli Priscoli, Wolf, 2010). Rządy Tajlandii, Kambodży, Laosu oraz Wietnamu Południowego upoważniły swoich przedstawicieli do podejmowania wiążących decyzji na forum organizacji. Państwa indochińskie stanęły głównie przed koniecznością przeprowadzenia wielu badań i analiz, które sfinansowano ze środków przyznanych przez ONZ i inne kraje zainteresowane sytuacją w regionie. 
Z pomocą Administracji Narodów Zjednoczonych ds. Pomocy Technicznej (UN Technical Assistance Administration) powołano komisję pod przewodnictwem gen. Raymonda Wheelera. Zebrała ona wiele informacji dotyczących stanu hydrologicznego i geologicznego dorzecza, prezentując zebrane dane w wydanym w lutym 1958 roku dokumencie (Osborne, 2004a). Opis dorzecza uzupełniał opublikowany w 1961 roku raport komisji prof. Gilberta White’a, którego zespół dokonał rzetelnej społeczno-ekonomicznej charakterystyki regionu (CCILWB Committee for the Coordination of Investigations of the Lower Mekong Basin, 1968).

Sytuacja w Indochinach robiła się coraz bardziej napięta, co doprowadziło ostatecznie do lądowania wojsk amerykańskich w Wietnamie w marcu 1965 roku i II wojny indochińskiej. Mimo trwającego konfliktu kraje Mekongu próbowały podejmować wspólne inicjatywy w zakresie hydropolityki. Z pomocą Stanów Zjednoczonych przeprowadzono badania nad możliwościami budowy tamy $\mathrm{Pa}$ Mong w Laosie, której moc miała sięgać 4800 MW. Bangkok i Wientian z kolei podpisały umowę dotyczącą eksploatacji rzeki Nam Ngum. W roku 1970 został przyjęty Orientacyjny Plan Dorzecza (Indicative Basin Plan), który wyznaczał m.in. strategię rozwoju hydroenergetyki na najbliższe 30 lat. Zakładał on budowę ok. 180 obiektów w dorzeczu o różnym przeznaczeniu, z czego w najbliższym dziesięcioleciu miały powstać hydroelektrownie o łącznej mocy 3272 MW (MRC, 2013). Pięć lat po ogłoszeniu planu przyjęto ostateczną wersję Karty wody, która zawierała reguły zarządzania rzekami regionu. Opracowano również Wspólną deklarację zasad (Joint Declaration on Principles), definiującą sprawiedliwe i rozsądne korzystanie z wód Mekongu, która nie doczekała się jednak ratyfikacji. Co ważne, dokument ten uznawał dopływy za integralną część głównego nurtu, wymuszając konieczność konsultacji w wypadku planowanych inwestycji w całym dorzeczu.

Rok 1975, który przyniósł zakończenie wojny w Indochinach, skomplikował hydropolityczną sytuację w regionie. W zjednoczonym Wietnamie oraz w Laosie władzę przejęli komuniści, którzy wyrażali chęć dalszej współpracy. Nowy rząd Czerwonych Khmerów w Kambodży zaczął jednak izolować kraj od świata zewnętrznego. Dlatego też w kwietniu 1977 roku podczas pierwszego spotkania po długiej przerwie zdecydowano o przekształceniu komitetu w organizację trójpodmiotową. Ostatecznie doszło do tego 5 stycznia 1978 roku, kiedy powołano Tymczasowy Komitet ds. Koordynacji i Badań Dolnego Mekongu (Interim Committee for Coordinationa of Investigations of Lower Mekong Basin) (CCILWB, 1981). Po obaleniu reżimu Pol Pota na początku 1979 roku 
i ustanowieniu prowietnamskiego rządu w Kambodży pojawiła się szansa na wznowienie współpracy we wcześniejszym formacie. Sytuacji sprzyjał sojusz Hanoi z Wientianem, który przełożył się również na wzrost liczby wspólnych inicjatyw hydropolitycznych. Relacje na Półwyspie Indochińskim skomplikowały się jednak ponownie, kiedy to doszło do incydentów na granicy tajsko-laotańskiej. W grudniu 1984 roku żołnierze Tajlandii zauważyli, iż Laotańczycy kopią tunele wodne tak, by trzy wioski znalazły się pod jurysdykcją władz w Wientian. Do eskalacji sporu doszło w 1987 roku, gdy w regionie pojawiły się wojska laotańskie, a tajskie jednostki wkroczyły na sporne tereny. Starcia pochłonęły ok. 1000 ofiar, jednak dzięki działaniom specjalnie powołanej komisji granicznej udało się zażegnać konflikt. Incydenty nie przeszkodziły jednak współpracy laotańsko-tajskiej, bowiem nadal prowadzono rozmowy dotyczące budowy hydroelektrowni Nam Ngum 3.

Na początku lat 90. doszło do kilku spotkań z delegatami z Phnom Penh, co zaowocowało 24 czerwca 1991 roku ponownym przyjęciem Kambodży na łono Tymczasowego Komitetu. Nazwa pozostała jednak bez zmian, gdyż kraje dolnej części dorzecza rozpoczęły jednocześnie negocjacje na temat utworzenia nowej organizacji regionalnej. W czasie rozmów szczególnie aktywna była Tajlandia, która sprzeciwiała się wpływom ONZ, co doprowadziło ostatecznie do ustąpienia przedstawiciela wykonawczego wskazywanego przez Narody Zjednoczone (IMC - The Interim Mekong Committee, 1992). Pojawiły się również rozbieżności między Tajlandią a Wietnamem, co omal nie doprowadziło do zerwania negocjacji. Rząd w Bangkoku chciał bowiem, aby działania w dopływach mogły być podejmowane bez konsultacji z pozostałymi stronami, by swobodnie móc realizować swoje plany przerzutów wody z dorzecza Mekongu na tereny o wysokim niedoborze. Hanoi było temu przeciwne, jednak wydaje się, że ze sporu zwycięsko wyszła Tajlandia, która przeforsowała proponowane zapisy. Podczas prac nad utworzeniem nowej instytucji można było dostrzec wiele rozbieżności i konflikt interesów, ale rozmowy zakończyły się sukcesem. 5 kwietnia 1995 roku doszło do podpisania Umowy o współpracy na rzecz zrównoważonego rozwoju dorzecza Mekongu (Agreement on the Cooperation for the Sustainable Development of the Mekong River Basin), która powołała do życia Komisję Rzeki Mekong (MRC - Mekong River Commission) (Bearden, 2010). Rozmowom towarzyszyła również intensyfikacja współpracy bilateralnej między Laosem i Tajlandią. Dyskutowano o możliwościach współpracy wokół budowy i sprzedaży energii z obiektów na rzece Nam Theun oraz elektrowni Nam Ngum 3. Wientian z kolei zaproponował rządowi w Bangkoku sprzedaż 
wody pitnej, która miałaby powędrować na tereny o dużym deficycie specjalnie wybudowanymi rurociągami.

Nowa organizacja miała przede wszystkim za zadanie skoordynować współpracę w dorzeczu zwłaszcza w perspektywie ambitnych planów rozbudowy sektora energetyki wodnej w Indochinach. Prawdziwym wyzwaniem dla Komisji Rzeki Mekong i państw dolnego biegu stały się jednak chińskie plany budowy kaskady tam w prowincji Yunnan. Skutki wypełniania ich rezerwuarów były już odczuwalne podczas rozmów nad utworzeniem MRC, kiedy dochodziło do spadków poziomu wody. Dlatego też mimo braku chęci ze strony ChRL co do członkowstwa w organizacji, kraje Komisji starały się nakłonić Pekin do współpracy. Chiny ostatecznie wyraziły chęć utrzymania relacji w innej formule i tak w lipcu 1996 roku wraz z Birmą zostały oficjalnie partnerem dialogu Komisji Rzeki Mekong (Than, Abonyi, 2001).

W październiku 1996 roku doszło do pewnych tarć na linii Bangkok Wientian, kiedy to przedstawiciele Tajlandii przybyli z oficjalną wizytą w celu negocjowania cen za energię elektryczną. Laos uznał, że stawki zaproponowane przez tajskich partnerów są zbyt niskie, na co druga strona odpowiedziała odstąpieniem od umowy zakupu elektryczności. Ostatecznie jednak kraje doszły do porozumienia. Mimo zacieśniającej się współpracy w ramach MRC do sporu doszło również między rządem w Phnom Penh a władzami w Hanoi. Pierwsze spięcia miały miejsce jeszcze 1996 roku, kiedy uwolnienie wody spowodowane awarią podczas budowy hydroelektrowni Yali Falls doprowadziło do podtopień we wschodniej części Kambodży. Mimo zapewnień wietnamskiej strony o podjęciu odpowiednich kroków i zapobieganiu takim sytuacjom w przyszłości do podobnych incydentów dochodziło dość często. By rozwiązać sprawę polubownie, komisja wystąpiła $\mathrm{z}$ wnioskiem o wspólne spotkanie przedstawicieli Kambodży i Wietnamu, podczas którego ci pierwsi skrytykowali sąsiada i zażądali rekompensat. Hanoi zapewniało jednak, że nie były to celowe działania, lecz jedynie efekt problemów technicznych (Osborne, 2004b).

W nowym tysiącleciu coraz większy wpływ na zarządzanie wodami Mekongu miała sytuacja w chińskiej części dorzecza. Między wrześniem a październikiem 2001 roku doszło w Indochinach do podtopień, które były efektem uwolnienia wody z rezerwuaru tamy Manwan. W rezultacie państwa Komisji Rzeki Mekong rozpoczęły rundę rozmów na temat zarządzania antykryzysowego i zapobiegania negatywnym skutkom powodzi, co doprowadziło do wypracowania wieloramowej strategii na najbliższe 10 lat. Informacje o budowie kolejnej tamy w chińskiej części dorzecza przyczyniły się do intensyfikacji spotkań i warsztatów w gronie 
państw indochińskich oraz powołania Forum Powodziowego Mekongu. Sukcesem MRC było również podpisanie 1 kwietnia 2002 roku umowy z Chinami, na mocy której Państwo Środka zobowiązało się do udostępniania krajom indochińskim danych hydrologicznych (MRC, 2008). W listopadzie tego roku państwa dolnego Mekongu przyjęły również regulacje związane z procedurami informowania, konsultacji i podpisywania umów między członkami MRC (Procedures for Notification, Prior Consultation and Agreement) w odniesieniu do podejmowanych w dorzeczu działań. W obliczu kolejnych problemów w postaci niskiego poziomu wody odnotowanego między marcem a kwietniem 2004 roku, państwa indochińskie postanowiły ulepszyć proces monitorowania sytuacji w dorzeczu. Usprawniono wymianę danych hydrologicznych oraz ustalono minimalny przepływ wody na Mekongu w porze suchej.

W 2006 roku doszło do podpisania wstępnej umowy między Laosem a malezyjską firmą, która podjęła się budowy położonej przy granicy z Kambodżą tamy Don Sahong. Pełni obaw Khmerowie wystosowali w połowie 2007 roku oficjalny protest do rządu laotańskiego, który nie spotkał się z żadnym odzewem. Do sprawy powrócono podczas spotkania Komisji Rzeki Mekong jeszcze tego samego roku w listopadzie, kiedy to poproszono o ponownie dokonanie oceny skutków funkcjonowania tego obiektu. Oficjalny dokument, krytyczny wobec laotańskiego pomysłu, nie został jednak poważnie potraktowany przez władze $\mathrm{w}$ Wientian i nie trafił do szerszej rzeszy zainteresowanych. Wsparcia Laosowi udzieliła jednak Tajlandia, do której ma płynąć pozyskiwana w hydroelektrowni Don Sahong energia. Tym samym doszło do pierwszego poważnego zgrzytu na łonie Komisji Rzeki Mekong, a z czasem spotykała ją coraz większa krytyka za brak skuteczności w rozwiązywaniu sporów (Osborne, 2004a).

Aby odeprzeć zarzuty MRC, występowała z licznymi inicjatywami. Jedność państw indochińskich wyrażano również poprzez podpisywanie szeregu umów takich jak porozumienie tajsko-wietnamskie z lipca 2009 roku o poszanowaniu zasobów regionu czy umowa dotycząca żeglugi między rządem w Phnom Penh a Wietnamem (Onishi, 2011). Rozdźwięk w grupie państw członkowskich był jednak widoczny chociażby na przykładzie stosunku do chińskich działań. W 2010 roku Tajlandia oskarżyła Chiny o doprowadzenie do suszy na Półwyspie, a w obronie Państwa Środka wystąpiła Kambodża. Te wydarzenia sprawiły, że na pierwszym Szczycie Mekongu, który miał miejsce w kwietniu tego samego roku i w którym brali udział przedstawiciele wszystkich państw dorzecza, kwestia chińskich tam zdominowała pozostałe tematy. We wrześniu z kolei Laos przesłał do MRC pierwszy raport dotyczący potencjalnych skutków budowy 
Xayaburi - kolejnej elektrowni wodnej w głównym nurcie. Wietnam, obawiający się negatywnych efektów funkcjonowania tej hydroelektrowni, wezwał do 10-letniego moratorium w kwestii budowy obiektów na Mekongu, co poparła również Kambodża (Pearse-Smith, 2012). Mimo zapewnień laotańskich władz, że realizacja nie rozpocznie się bez uprzednich badań i analiz, w czerwcu 2011 roku wydano zgodę na rozpoczęcie prac konstrukcyjnych. Protesty Hanoi i Phnom Penh na nic się zdały, a do Laosu popłynęły pieniądze z tajskich banków. Podczas oficjalnego otwarcia placu budowy obecni byli przedstawiciele wszystkich państw dolnego biegu Mekongu. Delegacje Kambodży i Wietnamu stwierdziły jednak, że nie wprowadzono zmian, o których zapewniał Wientian, i oskarżyły Laos o dezinformację. $Z$ tego też względu podczas spotkania w ramach jednego z organów Komisji Rzeki Mekong w styczniu 2013 roku reprezentanci władz w Hanoi i Phnom Penh zajęli się ponownie sprawą hydroelektrowni Xayaburi. Pewne sugestie poparła również żywo zainteresowana projektem Tajlandia. Laos w geście protestu odmówił podpisania protokołu końcowego ze spotkania, a w październiku poinformował Komisję o zamiarze rozpoczęcia budowy obiektu Don Sahong w niedalekiej przyszłości. Uznano bowiem, iż nie jest konieczna zgoda pozostałych państw dolnej części dorzecza, gdyż tama leży rzekomo w jednym z kanałów, a nie w głównym nurcie Mekongu (Zaręba, 2015). Do złagodzenia sporów nie doprowadził również drugi Szczyt Mekongu w kwietniu 2014 roku, kiedy to wyraźnie zarysowała się koalicja laotańsko-tajska z jednej strony i kambodżańsko-wietnamska z drugiej. Mimo kontrowersji odnośnie do budowy Don Sahong prace konstrukcyjne rozpoczęto w październiku 2015 roku.

Rosnącym animozjom na Półwyspie przyglądały się przede wszystkim Chiny, ale zainteresowanie sytuacją w regionie wykazywały również Stany Zjednoczone i Japonia. Dlatego też w listopadzie 2014 roku premier ChRL Li Keqiang zaproponował powstanie nowej inicjatywy, która obejmowałaby wszystkie państwa dorzecza. Spotkanie ministrów, które odbyło się w kolejnym roku, utwierdziło tylko kraje regionu w przekonaniu o konieczności powołania takiego forum. Do jego powstania doszło 23 marca 2016 roku, a mechanizm współpracy Lancang- Mekong (LMCM - Lancang-Mekong Cooperation Mechanism) zarysował nowe ramy hydropolityki w dorzeczu (Middleton, Allouche, 2016). 


\section{PODSUMOWANIE}

Kraje dolnego biegu rzeki Mekong od chwili powstania pierwszej regionalnej organizacji starały się współpracować wokół zasobów wody. Wspólnym działaniom nie przeszkodziły nawet poważne konflikty, które destabilizowały sytuację w regionie. Państwa indochińskie zdają sobie bowiem sprawę ze znaczenia zasobów rzeki Mekong dla ich stabilności gospodarczej, dlatego też podejmują wspólne inicjatywy i zacieśniają współpracę w wielu dziedzinach hydropolityki. Największą pokusą, w szczególności dla najbiedniejszych państw regionu takich jak Laos i Kambodża, jest rozwój hydroenergetyki. Dochody ze sprzedaży energii elektrycznej czy udzielania koncesji mogłyby znacznie zasilić budżety tych dwóch krajów. Co więcej, dzięki elektrowniom wodnym elektryczność dotarłaby na tereny, gdzie wcześniej występowały trudności w dostawie prądu.

Potencjalny boom w energetyce wodnej niesie jednak wiele negatywnych konsekwencji takich jak ryzyko powodzi w krajach sąsiednich czy możliwość pojawienia się suszy w okresie o małej intensywności opadów. Zdaje się, że państwa Półwyspu Indochińskiego chcą podążać udeptaną już ścieżką i kontynuować realizację planu hydroenergetycznej ekspansji w regionie. Konflikty, jakie pojawiły się chociażby wokół tamy Yali Falls w Wietnamie czy Don Sahong i Xayaburi w Laosie, nie wydają się wystarczającym argumentem za spowolnieniem tempa rozwoju energetyki wodnej. Z jednej strony na szali kładzie się zaspokojenie potrzeb energetycznych wciąż rozwijających się gospodarek indochińskich, $\mathrm{z}$ drugiej zaś ochronę środowiska w dorzeczu i stabilność rolnictwa czy rybołówstwa. To z kolei może doprowadzić tylko do wzrostu liczby sporów wokół zasobów wody i zasiać kolejne ziarno niezgody w regionie. Liczne inwestycje w Laosie i Kambodży, które przeprowadziły firmy chińskie, tajskie czy wietnamskie, pokazują, że problem jest bardziej złożony. Niewykluczone również, że Laos i Kambodża prowadzą swoją hydropolityczną grę, aby zbalansować wpływy państw sąsiednich i wydźwignąć się z gospodarczej stagnacji.

Wydaje się, że wzrost inwestycji w hydroenergetyce na Półwyspie Indochińskim i potencjalne pojawienie się nowych sporów może doprowadzić do marginalizacji Komisji Rzeki Mekong. Co więcej, w obliczu chińskich działań w górnej części dorzecza dobrym rozwiązaniem może być utworzenie ciała obejmującego wszystkie kraje regionu, takiego jak wspomniany mechanizm współpracy Lancang-Mekong. Dla Chin rosnące animozje w łonie państw MRC są idealną okazją do przejęcia inicjatywy i wprowadzenia reguł gry, którym być może będą musiały się podporządkować wszystkie państwa indochińskie. 
Bibliografia:

Baran, E., Jantunen, T., Chong, C.K. (2007). Values of Inland Fisheries in the Mekong river basin. Phnom Penh: World Fish Center.

Bartley, D., Jorgensen J. (2010). Inland Fisheries and Aquaculture. Pobrane z: www.fao. org.

Bearden, B. (2010). The legal regime of the Mekong River a look back and some proposals for the way ahead. Water Policy, 12, 237-261.

Committee for the Coordination of Investigations of the Lower Mekong Basin (1968). Annual Report 1967. Bangkok: United Nations Economic Commission for Asia and the Far East.

Committee for the Coordination of Investigations of the Lower Mekong Basin (1981). Annual Report 1980. Bangkok: United Nations Economic Commission for Asia and the Far East.

Delli Priscoli, J., Wolf, A. (red.). (2010). Managing and Transforming Water Conflicts. Nowy Jork: Cambridge University Press.

Foran, T., Manorom, K. (2009). Pak Mun Dam: Perpetually Contested? W: F. Molle, T. Foran, M. Käkönen (red.), Contested Water Scapes in the Mekong Region: Hydropower, Livelihoods and Governance (s. 55-80). Chiang Mai.

General Statistics Office of Vietnam (2011). Agriculture, Forestry and fishery. Pobrane Z: www.gso.gov.vn.

Gillett, R. (2004.) The Marine Fisheries of Cambodia. Pobrane z: www.fao.org.

Goh, E. (2007). Developing the Mekong. Regionalism and regional security in ChinaSouth East Asian relations. Londyn: Routledge.

Lawrence, S. (2009). The Nam Theun 2 Controversy and its lessons for Laos. W: F. Molle, T. Foran, M. Käkönen (red.), Contested Water Scapes in the Mekong Region: Hydropower, Livelihoods and Governance (s. 81-110). Chiang Mai.

Mekong River Commission (2008). Agreement on provision of hydrological information renewed by China and MRC. Wientian: MRC Secretariat.

Mekong River Commission (2010). State of the Basin Report. Wientian: MRC Secretariat.

Mekong River Commission (2011). Working Towards an IWRM-Based Basin Development Strategy for the Lower Mekong Basin. Wientian: MRC Secretariat.

Mekong River Commission (2013). Mekong Basin Planning. The Story Behind the Basin Development Plan. Wientian: MRC Secretariat.

Middleton, C., Allouche, J. (2016). Watershed or Powershed? Critical Hydropolitics, China and the "Lancang-Mekong Cooperation Framework". The International Spectator, 51(3), 100-117.

Molle, F., Foran T., Floch P. (2009). Introduction: Changing Waterscapes in the Mekong Region - Historical Background and Context. W: F. Molle, T. Foran, M. Käkönen (red.), Contested Water Scapes in the Mekong Region: Hydropower, Livelihoods and Governance (s. 1-19). Chiang Mai. 
Onishi, K. (2011). Reassessing Water Security in the Mekong The Chinese Rapprochement with Southeast Asia. Journal of Natural Resources Policy Research, 3(4), $393-412$.

Osborne, M. (2004a). The Mekong. River under Threat. Pobrane z: www.lowyinstitute. org.

Osborne, M. (2004b). River at Risk. Mekong and the water politics of China and Southeast Asia. Pobrane z: www.lowyinstitute.org.

Pearse-Smith, S. (2012). "Water war" in the Mekong Basin? Asia Pacific Viewpoint, 5(2), $147-162$.

Snidvongs, A., Teng S.-K. (2006). GIWA Regional assessment 55. Pobrane z: www.unep. org.

Than, M. Abonyi, G. (2001). The Greater Mekong Subregion. Co-operation in Infrastructure and Finance. W: M. Than, C.L. Gates (red.), ASEAN Enlargement: Impacts \& Implications (s. 128-163). Singapur: Institute of Southeast Asian Studies.

The Interim Mekong Committee (1992). Preparing for new challenges. The Interim Mekong Committee Annual Report 1991. Bangkok.

Tilt, B. (2014). International Mekong River Basin: Events, Conflicts or Cooperation, and Policy Implications. Pobrane z: www.transboundarywaters.orst.edu.

Zaręba, M. (2015). Hydropolityka w regionie rzeki Mekong. Między konfliktem a wspótpraca. Łódź: Uniwersytet Łódzki, Wydział Filozoficzno-Historyczny. 